\title{
Prognostic factors of neuroinflammation and oxidative stress in brain injury patients at Cipto Mangunkusumo Hospital Jakarta
}

\author{
Renindra A. Aman, ${ }^{1}$ Syaiful Ichwan, ${ }^{1}$ Alida Harahap, ${ }^{2}$ Yusuf Wibisono, ${ }^{l}$ Nia Yuliatri, ${ }^{l}$ Mohammad A. Aulia,${ }^{1}$
} Hans-Joachim Freisleben ${ }^{3}$

${ }^{1}$ Department of Neurosurgery, Faculty of Medicine, Universitas Indonesia, Jakarta, Indonesia

${ }^{2}$ Department of Clinical Pathology, Faculty of Medicine, Universitas Indonesia, Jakarta, Indonesia

${ }^{3}$ Medical Research Unit, Faculty of Medicine, Universitas Indonesia, Jakarta, Indonesia

\begin{abstract}
Abstrak
Latar belakang: Penelitian ini bertujuan untuk menentukan hubungan antara neuroinflamasi dan stress oksidatif dengan prognosis pasien cedera otak dan hubungan antara tindakan bedah saraf dengan kondisi neuroinflamasi dan stress oksidatif.

Metode: Desain penelitian adalah studi observasional prospektif pada 40 pasien cedera otak yang dioperasi. Pengukuran kadar IL-6, asam urat, MDA, antibodi NR2A dan GSH serum pasien cedera otak dilakukan sebelum dan sesudah operasi. Dilakukan pula penilaian hubungan seluruh variabel tersebut dengan GCS, GOS dan tindakan bedah saraf.

Hasil: Kadar IL6 pascaoperasi cenderung menurun bila dibandingkan dengan kadar IL6 praoperasi, dengan rerata penurunan -190,61 pg/mL. Kadar IL6 pascaoperasi berhubungan bermakna dengan GCS hari ke-7 (nilai p = 0,006), dengan OR 24. Kadar IL6 pascaoperasi berhubungan bermakna dengan GOS bulan ke-3 (nilai p =0,016) dengan OR 11,6. Kadar asam urat pascaoperasi cenderung menurun bila dibandingkan dengan kadar praoperasi, dengan rerata penurunan $-0,26 \mathrm{mg} / \mathrm{dL}$. Terdapat perbedaan bermakna antara rerata kadar asam urat pascaoperasi pasien dengan GCS hari ke-7 $\leq 8$ sebesar 4,16 mg/dL dengan rerata kadar asam urat pascaoperasi pada kelompok pasien dengan GCS hari ke-7 > 8 sebesar 2,71 mg/dL (nilai $p=0,042$ ). Kadar MDA pasca operasi cenderung menurun bila dibandingkan dengan kadar praoperasi, dengan rerata penurunan -0,08 mmol/mL. Tidak ada hubungan bermakna antara kadar MDA dengan GCS dan GOS. Tidak ditemukan hubungan bermakna antara kadar antibodi NR2A dan GSH dengan GCS, GOS dan tindakan bedah saraf. Dari hasil analisis multivariat, variabel terkuat yang berhubungan dengan GCS dan GOS adalah IL-6.
\end{abstract}

Kesimpulan: Proses neuroinflamasi dan stres oksidatif memiliki nilai prognostik pada pasien cedera otak. Tindakan bedah saraf dapat mengurangi proses neuroinflamasi. (Med J Indones. 2012;21:152-9)

\begin{abstract}
Background: This study aims to determine the association between neuroinflammation and oxidative stress with prognosis of brain injury patients and the association between neurosurgical procedure with neuroinflammation and oxidative stress condititons.

Methods: The study design is a prospective observation of 40 brain injury patients who underwent surgery. IL-6, uric acid, MDA, NR2A antibodies and GSH serum level of pre- and 1 day post-operation on brain injury patients were measured, and their association with GCS, GOS and neurosurgical procedures were analyzed.

Results: The post-operative IL-6 serum level showed a downward trend compared to pre-operative value (mean decrease: $-190.61 \mathrm{pg} / \mathrm{mL})$. The post-operative IL-6 level was significantly associated with GCS 7 days post-operation $(\mathrm{p}=0.006)$, with OR 24. The post-operative IL-6 serum level was significantly associated with GOS 3 months post-trauma $(\mathrm{p}=0.016)$ with OR 11.6. The post-operative uric acid serum level showed a downward trend compared to pre-operative value (mean decrease: $-0.26 \mathrm{mg} / \mathrm{dL}$ ). There was a significant difference between the mean value of post-operative uric acid serum level in patients with 7 days post-trauma with GCS $\leq 8$ (mean: $4.16 \mathrm{mg} / \mathrm{dL}$ ) and GCS $>8$ (mean: $2.71 \mathrm{mg} / \mathrm{dL}$ ), $(\mathrm{p}=0.042)$. The post-operative MDA serum level showed a downward trend compared to pre-operative value (mean decrease: $-0.08 \mathrm{nmol} /$ $\mathrm{mL}$ ). There is no significant association between MDA serum level, GCS and GOS and no significant association of NR2A antibody and GSH serum level with GCS, GOS and neurosurgical procedure. From the multivariate analysis, the most important neuroinflammatory variable associated with GCS and GOS is IL-6.

Conclusion: Neuroinflammation and oxidative stress may have prognostic values in brain-injured patients, in particular IL-6. Neurosurgical procedures may decrease the neuroinflammation process (Med J Indones. 2012;21:152-9)
\end{abstract}

Keywords: Neuroinflammation, oxidative stress, traumatic brain injury, neurosurgical procedures, interleukin 6, uric acid, malondialdehyde, NR2A antibody, glutathione

In many developing and developed countries, trauma is the leading cause of mortality in the age group under 45 years, causing far more losses of people in productive age than cardio- and cerebrovascular diseases or malignancy. In the traumatic group, brain injury causes about $50 \%$ of mortality.
In developed countries such as U.S.A, mortality due to brain injury reaches $43 \%$ of all mortality from trauma. $^{2}$ During the last decades, 1.5 to 2.0 million people suffered from brain injuries each year; about 250,000 of these patients required hospitalization and about 52,000 died. In 1985, prolonged post-traumatic 
care became an economic burden, spending 4.5 billion USD in America, and currently causes health-care expenses of 11 billion USD every year in 11 Southeast Asian countries. The "World report on traffic injury prevention" in the 2004 WHO publication titled "Violence and injury prevention section" stated that by 2020, road traffic accidents will occupy the third rank in public health burden worldwide. ${ }^{3}$

Traumatic brain injury consists of primary injury related to biomechanical trauma and secondary damage. Secondary brain damage is triggered by post-traumatic hypoxia in brain tissue, which induces a cascade of destructive biochemical reactions on the cellular level, leading to additional mortality of nerve cells. ${ }^{4,5}$ This cascade of reactions comprises free radicals release, neuroinflammation and apoptosis, which are considered to worsen the primary brain injury and to influence the outcome of patients.

Secondary brain damage as a result of neuroinflammation is due to the release of inflammatory mediators, especially interleukin 6 (IL-6), the primary regulator of neuroinflammatory reactions. High levels of IL-6 in acute phase of brain injury is allegedly associated with the degree of brain damage, ${ }^{4,5}$ including bloodbrain barrier damage, which may lead to brain tissue ischemia. Due to post-brain injury blood-brain barrier damage, it is assumed that IL- 6 will be increased in the serum of patients with severe brain injury. ${ }^{6}$

Increased amount of free radicals that exceed the endogenous antioxidant capacity lead to oxidative stress, which can cause destruction of lipid, protein and DNA. ${ }^{7}$

Uric acid is the product of endogenous purine breakdown from reactions catalyzed by xanthine oxidase. Increased activity of xanthine oxidase occurs in ischemic conditions and in response to the increased amounts of pro-inflammatory cytokines. A byproduct of the reaction catalyzed by xanthine oxidase is superoxide radical, which aggravates oxidative stress (Figures 1 and 2). Serum uric acid level measurement is expected to represent xanthine oxidase activity. ${ }^{8}$

Increased reactive oxygen species (ROS) as the product of serial enzymatic reactions or due to mitochondrial dysfunction in secondary brain injury can induce lipid peroxidation (LPO) and lead to post-traumatic neuronal degeneration. Because of the difficulty to measure free radicals directly, alternative method to assess their involvement in brain injury is by the LPO byproducts measurement, such as malondialdehyde (MDA). ${ }^{9}$

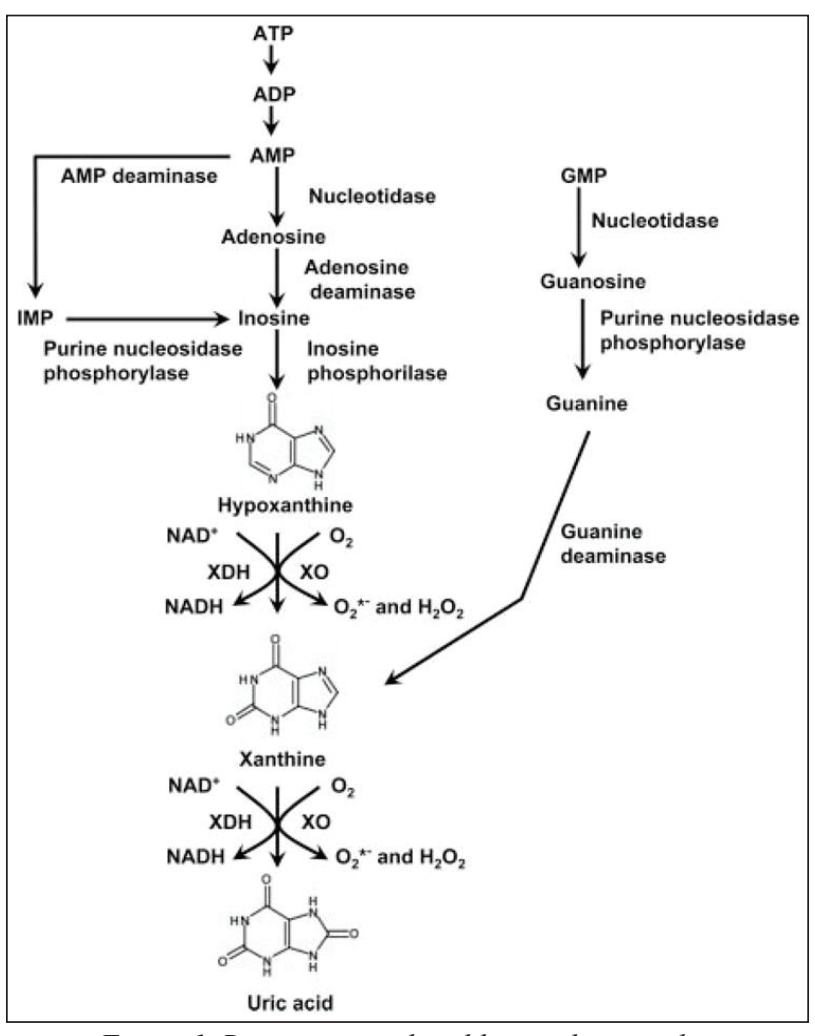

Figure 1. Reactions catalyzed by xanthine oxidase

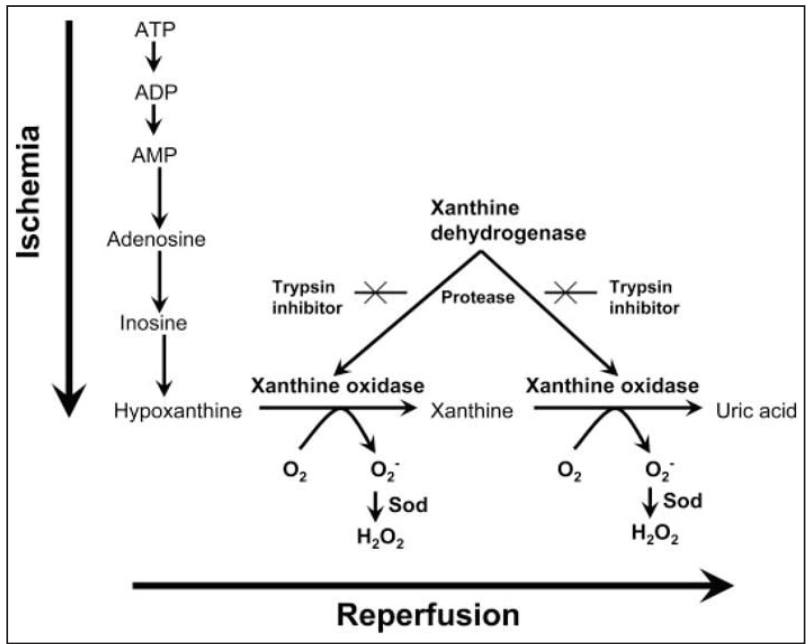

Figure 2. Effects of ischemia and reperfusion on reactions catalyzed by xanthine oxidase

Glutathione (GSH), a tripeptide thiol, is an important substance in the defense mechanisms against free radicals and hydroperoxides. GSH functions in the storage and transportation of cysteine, in maintaining protein and thiol reduction status, and in protecting cells from toxic components such as ROS, drugs or heavy metals. GSH acts as an endogenous antioxidant. ${ }^{10,11}$

Ischemic condition may stimulate cascades of neurotoxic reactions, in which excitated N-methyl-d- 
aspartate (NMDA) receptor acts as the main regulator of neural cell membranes and may cause biochemical changes in brain tissues, blood brain barriers and vessels. Calcium $\left(\mathrm{Ca}^{2+}\right)$ influx through the channels of NMDAR may potentiate mitochondrial depolarisation and increase superoxide radical production from mitochondria. Blood-brain barrier damage and activation of thrombin-activated serine protease can make a gap in synaptic NMDA receptors. Increased concentrations of peptides produced from a specific NMDAR gap in the brain can be released into the systemic blood circulation, e.g. NR2A. The latter may act as antigen initiating the immune response that leads to the emergence of autoantibodies in the blood. NR2A antibody measurement was used to assess NMDAR activation and could thus have prognostic value in brain injury patients, ${ }^{9,12}$ similar to before-mentioned IL-6 (representing neuroinflammation) and uric acid, MDA, and GSH serum level (representing oxidative stress).

For assessment of brain injury patient awareness in the acute phase, the GCS scoring system (Glasgow Coma Scale) is universally used. Patients are categorized as in 'coma' if the GCS score is under $8(\mathrm{GCS}<8)$. For assessment of the patients' outcome, the GOS scoring system (Glasgow Outcome Scale) is generally used. The GCS 7 days post-trauma and GOS at 1 month and 3 months post-trauma are the variables that represent the patient's prognosis.

The neurosurgical procedures that are considered to be able to stop or slow down the secondary brain damage are decompression, either by decompressive craniectomy or hematoma evacuation.

\section{METHODS}

This prospective observational study was conducted on 40 patients with brain injury who underwent surgery. ${ }^{13,14}$ IL-6, uric acid, MDA, NR2A antibodies and GSH serum levels in post-traumatic and preoperative patients (initial values) and 1 day after brain surgery (post-operative values) were measured. The prognostic association of the initial (pre-operative) and one day post-operative serum levels of these neuroinflammation and oxidative stress parameters with the initial GCS, GCS 7 days post-trauma, GOS 1 month and 3 months post-trauma were determined. Furthermore, the association between the neurosurgical procedures and the postoperative condition of the patients was analyzed.

IL-6 and NR2A antibodies serum levels were measured by ELISA. Uric acid serum level was measured by automated blood chemistry testing tool in the Clinical Pathology Laboratory of Cipto Mangunkusumo Hospital. The measurement of serum levels of MDA and GSH was done in collaboration with the laboratory of the Department of Biochemistry and Molecular Biology, Faculty of Medicine, Universitas Indonesia. Data was collected from August 2010 to April 2011.

\section{RESULTS}

Forty subjects were categorized and divided according to sociodemographic criteria, consciousness status (GCS score), diagnosis, neurosurgical procedure, quality of life (GOS score), and IL-6, uric acid, MDA, NR2A antibody and GSH serum levels (Table 1).

Table 1. Distribution of subjects ( $\mathrm{n}=40)$ according to sociodemographic criteria, consciousness status (GCS score), diagnosis, neurosurgical procedure, quality of life (GOS score), and serum levels of IL-6, uric acid, MDA, NR2A antibody and GSH

\begin{tabular}{ll}
\hline \multicolumn{1}{c}{ Criteria } & \multicolumn{1}{c}{ Results } \\
\hline Age & mean: 30.78 years \pm 15.43 \\
Sex $\quad$ & \\
$\quad$ female & $22.5 \%(9)$ \\
male & $77.5 \%(31)$ \\
Initial GCS & \\
GCS $\leq 8$ & $42.5 \%(17)$ \\
GCS $>8$ & $57.5 \%(33)$ \\
GCS on 7 days, posttraumatic & \\
GCS $\leq 8$ & $12.5 \%(5)$ \\
GCS $>8$ & $87.5 \%(35)$ \\
Diagnosis & \\
Epidural hematoma & $42.5 \%(17)$ \\
Cerebral contusion & $15 \%(6)$ \\
Epidural hematona \& cerebral contusion & $35 \%(14)$ \\
Cerebral contusion \& cerebral laceration & $2.5 \%(1)$ \\
Subdural hematoma & $5 \%(2)$
\end{tabular}


Neurosurgical procedure

Hematoma evacuation craniotomy

Decompressive craniectomy

Depressed fracture correction \& debridement

GOS 1 month, posttraumatic

unfavorable

favorable

GOS 3 months, posttraumatic

unfavorable

favorable

Initial IL-6 serum levels

Initial IL-6 serum levels

$\leq 100 \mathrm{pg} / \mathrm{mL}$

$>100 \mathrm{pg} / \mathrm{mL}$

Postoperative IL-6 serum levels

Postoperative IL-6 serumlevels

$\leq 100 \mathrm{pg} / \mathrm{mL}$

$>100 \mathrm{pg} / \mathrm{mL}$

Initial uric acid serum levels

Postoperative uric acid serum levels

Initial MDA serum levels

Postoperative MDA serum levels

Initial NR2A antibody serum levels

Initial NR2A antibody serum levels

$$
\begin{aligned}
& \leq 2 \mathrm{ng} / \mathrm{mL} \\
& <2 \mathrm{ng} / \mathrm{mL}
\end{aligned}
$$

Postoperative NR2A antibody serum levels

Postoperative NR2A antibody serum levels

$$
\leq 2 \mathrm{ng} / \mathrm{mL}
$$$$
<2 \mathrm{ng} / \mathrm{mL}
$$

Initial GSH serum levels
$80 \%(32)$

$17.5 \%(7)$

$2.5 \%(1)$

$37.5 \%(15)$

$62.5 \%(25)$

$15 \%(6)$

$85 \%(34)$

mean: $269.93 \mathrm{pg} / \mathrm{mL} \pm 521.76$

median: $76.74 \mathrm{pg} / \mathrm{mL}$

minimum: $0.08 \mathrm{pg} / \mathrm{mL}$

maximum: $2734.65 \mathrm{pg} / \mathrm{mL}$

$60 \%(24)$

$40 \%(16)$

mean: $79.31 \mathrm{pg} / \mathrm{mL} \pm 92.77$

median: $35.55 \mathrm{pg} / \mathrm{mL}$

minimum: $5.11 \mathrm{pg} / \mathrm{mL}$

maximum: $353.19 \mathrm{pg} / \mathrm{mL}$

$77.5 \%(31)$

$22.5 \%(9)$

mean: $3.15 \mathrm{mg} / \mathrm{dL} \pm 1.18$ median: $2.90 \mathrm{mg} / \mathrm{dL}$ minimum: $1.6 \mathrm{mg} / \mathrm{dL}$ maximum: $5.6 \mathrm{mg} / \mathrm{dL}$

mean: $2.89 \mathrm{mg} / \mathrm{dL} \pm 1.16$ median: $2.75 \mathrm{mg} / \mathrm{dL}$ minimum: $0.8 \mathrm{mg} / \mathrm{dL}$ maximum: $5.7 \mathrm{mg} / \mathrm{dL}$

mean: $0.47 \mathrm{nmol} / \mathrm{L} \pm 0.24$ median: $0.49 \mathrm{nmol} / \mathrm{L}$ minimum: $0.12 \mathrm{nmol} / \mathrm{L}$ maximum: $1.15 \mathrm{nmol} / \mathrm{L}$

mean: $0.39 \mathrm{nmol} / \mathrm{L} \pm 0.21$

median: $0.33 \mathrm{nmol} / \mathrm{L}$

minimum: $0.09 \mathrm{nMol} / \mathrm{L}$

maximum: $0.89 \mathrm{nmol} / \mathrm{L}$

mean: $4.48 \mathrm{ng} / \mathrm{mL} \pm 3.24$

median: $4.29 \mathrm{ng} / \mathrm{mL}$

minimum: $0.1 \mathrm{ng} / \mathrm{mL}$

maximum: $11.07 \mathrm{ng} / \mathrm{mL}$

$67.5 \%(27)$

$32.5 \%(13)$

mean: $3.78 \mathrm{ng} / \mathrm{mL} \pm 2.74$

median: $2.95 \mathrm{ng} / \mathrm{mL}$

minimum: $0.09 \mathrm{ng} / \mathrm{mL}$

maximum: $11.07 \mathrm{ng} / \mathrm{mL}$

$77.5 \%(31)$

$22.5 \%(9)$

mean: $0.58 \mu \mathrm{g} / \mathrm{mL} \pm 0.2$

median: $0.55 \mu \mathrm{g} / \mathrm{mL}$

minimum: $0.32 \mu \mathrm{g} / \mathrm{mL}$

maximum: $1.2 \mu \mathrm{g} / \mathrm{mL}$ 
Table 2. Association between initial serum levels and initial GCS (pre-operative)

\begin{tabular}{|c|c|c|c|c|c|}
\hline & \multicolumn{2}{|c|}{ Initial GCS } & & \multirow{2}{*}{$\begin{array}{l}\text { P value } \\
(\alpha<0.05)\end{array}$} & \multirow{2}{*}{$\begin{array}{l}\text { Prevalence } \\
\text { Rate }\end{array}$} \\
\hline & $\leq 8$ & $>8$ & & & \\
\hline \multicolumn{6}{|l|}{ Initial IL-6 serum level } \\
\hline$>100 \mathrm{pg} / \mathrm{mL}$ & $\begin{array}{c}12 \\
(75 \%)\end{array}$ & $\begin{array}{c}4 \\
(25 \%)\end{array}$ & 16 & & \\
\hline$\leq 100 \mathrm{pg} / \mathrm{mL}$ & $\begin{array}{c}5 \\
(20.8 \%)\end{array}$ & $\begin{array}{c}19 \\
(72.9 \%)\end{array}$ & 24 & 0.001 & 11.4 \\
\hline Total & $\begin{array}{c}17 \\
(42.5 \%)\end{array}$ & $\begin{array}{c}23 \\
(57 \%)\end{array}$ & 40 & & \\
\hline $\begin{array}{l}\text { Mean of initial uric acid serum } \\
\text { levels }\end{array}$ & $\begin{array}{l}3.5 \mathrm{mg} / \mathrm{dL} \\
\mathrm{N}=17\end{array}$ & $\begin{array}{l}2.89 \mathrm{mg} / \mathrm{dL} \\
\mathrm{N}=23\end{array}$ & & 0.142 & \\
\hline $\begin{array}{l}\text { Median of initial MDA serum } \\
\text { levels }\end{array}$ & $\begin{array}{l}0.54 \mathrm{mmol} / \mathrm{L} \\
\mathrm{N}=17\end{array}$ & $\begin{array}{c}0.38 \mathrm{mmol} / \mathrm{L} \\
\mathrm{N}=23\end{array}$ & & 0.106 & \\
\hline \multicolumn{6}{|l|}{$\begin{array}{l}\text { Initial NR2A antibody serum } \\
\text { levels }\end{array}$} \\
\hline$\geq 2 \mathrm{ng} / \mathrm{mL}$ & $\begin{array}{c}11 \\
(40.7 \%)\end{array}$ & $\begin{array}{c}16 \\
(59.3 \%)\end{array}$ & 27 & 1.0 & \\
\hline$<2 \mathrm{ng} / \mathrm{mL}$ & $\begin{array}{c}6 \\
(46.2 \%)\end{array}$ & $\begin{array}{c}7 \\
(53.8 \%)\end{array}$ & 13 & & \\
\hline Total & $\begin{array}{c}17 \\
(42.5 \%)\end{array}$ & $\begin{array}{c}23 \\
(57.5 \%)\end{array}$ & & & \\
\hline $\begin{array}{l}\text { Median of initial GSH serum } \\
\text { levels }\end{array}$ & $\begin{array}{c}0.59 \mathrm{mmol} / \mathrm{L} \\
\mathrm{N}=17\end{array}$ & $\begin{array}{l}0.52 \mathrm{mmol} / \mathrm{L} \\
\mathrm{N}=23\end{array}$ & & 0.511 & \\
\hline
\end{tabular}

There is a significant association between the initial IL-6 serum level and the initial GCS score, $p$ value: 0.001 and prevalence rate 11.4 (Table 2). The postoperative IL-6 serum level showed a downward trend compared to pre-operative value with a mean decrease of $-190.61 \mathrm{pg} / \mathrm{mL}$, $\mathrm{p}$ value: 0.001 (Table 3 ). The postoperative IL-6 serum level was significantly associated with GCS 7 days post-surgery $(p=0.006)$ with OR 24 , meaning that patients with post-surgical levels of IL-6 $<100 \mathrm{pg} / \mathrm{mL}$ had a 24-times higher chance of getting the 7-days post-traumatic GCS $>8$ (Table 4).

The post-operative IL-6 serum level was significantly associated with GOS 3 months post-trauma ( $p$ value: 0.016 ) with OR 11.6 , meaning that patients with postoperative IL-6 levels $<100 \mathrm{pg} / \mathrm{mL}$ had a 11.6 -times higher chance of reaching the 3 months post-traumatic 'favorable' GOS (Table 4).

The post-operative uric acid serum level had a downward trend compared to pre-operative value, with a mean decrease of $-0.26 \mathrm{mg} / \mathrm{dL}$ (Table 3). There was a significant difference between the mean post-operative uric acid serum levels in patients with 7-days posttrauma GCS $\leq 8$ (mean: $4.16 \mathrm{mg} / \mathrm{dL}$ ) and in patients with 7-days post-trauma GCS $>8$ (mean: $2.71 \mathrm{mg} / \mathrm{dL}$; $\mathrm{p}=0.042$; Table 4).

The post-operative MDA serum levels had a downward trend compared to pre-operative value, with a mean decrease of $-0.08 \mathrm{nmol} / \mathrm{mL}(\mathrm{p}=0.004$; Table 3$)$.

There was no significant association between surgery and GSH or NR2A antibody serum level (Table 3) and no significant association between MDA, GSH and NR2A antibody serum levels and GCS or GOS (Table 4).

From the multivariate analysis of the association between all variables with initial GCS, the neuroinflammation variable IL-6 was found to be related with the initial GCS (p value: 0.003 ) with OR 9.8 (95\% CI: $2.1-45.1)$.

From the multivariate analysis of relations between all variables with 7-days post-trauma GCS, the neuroinflammation variable IL- 6 was found to be related with the 7-days post-operative GCS (p value: 0.026 ), with OR 4 (95\% CI: 0.2 - 67.7). Neuroinflammation was the most important variable compared with uric acid towards GCS at day 7. 
Table 3. Pre- and post-operative differences of serum levels

\begin{tabular}{llcc}
\hline \multicolumn{1}{c}{ Variables } & \multicolumn{1}{c}{ Median } & $\begin{array}{c}\text { Standard } \\
\text { Deviation }\end{array}$ & $\begin{array}{c}\text { P value } \\
(\alpha<0.05)\end{array}$ \\
\hline Median of initial IL-6 & $76.74 \mathrm{pg} / \mathrm{mL}$ & & 0.0001 \\
Median of postoperative IL-6 & $35.55 \mathrm{pg} / \mathrm{mL}$ & & 0.143 \\
Mean of initial uric acid levels & $3.15 \mathrm{mg} / \mathrm{dL}$ & 1.18 & 0.004 \\
Mean of postoperative urid acid & $2.89 \mathrm{mg} / \mathrm{dL}$ & 1.16 & 0.125 \\
Median of initial MDA levels & $0.39 \mathrm{mmol} / \mathrm{L}$ & & \multirow{2}{*}{1.0} \\
Median of postoperative MDA & $0.33 \mathrm{mmol} / \mathrm{L}$ & & \\
Median of initial NR2A antibody levels & $4.29 \mathrm{ng} / \mathrm{mL}$ & & \\
Median of postoperative NR2A antibody & $2.95 \mathrm{ng} / \mathrm{mL}$ & & \\
Median of initial GSH levels & $0.55 \mathrm{mmol} / \mathrm{L}$ & & \\
Median of postoperativeGSH & $0.55 \mathrm{mmol} / \mathrm{L}$ & & \\
\hline
\end{tabular}

Table 4. Association of post-operative IL-6, uric acid, MDA, NR2A antibody and GSH with post-trauma GCS and GOS score

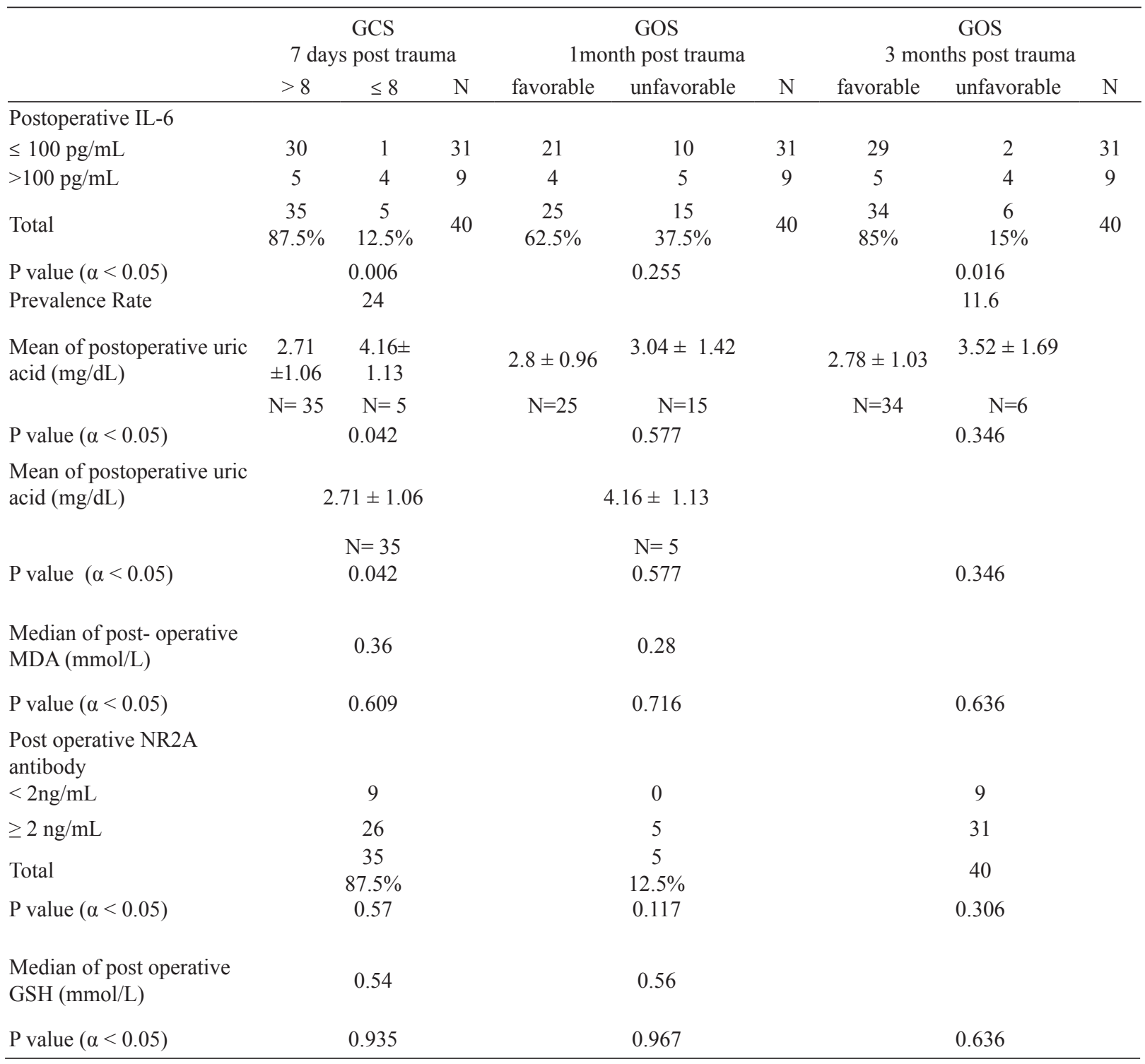


Multivariate analysis of relations between all variables and GOS 3 months post-trauma showed that the neuroinflammation variable IL-6 was related with GOS 3 months post-trauma ( $\mathrm{p}$ value: 0.031 ), with OR 10.6 (95\% CI: $1.4-81.6)$, meaning that patients with postoperative IL-6 levels $<100 \mathrm{pg} / \mathrm{mL}$ had a 10.6 -times better chance to achieve 3 months post-traumatic 'favorable' GOS as compared to patients with a post-operative IL-6 level $>100 \mathrm{pg} / \mathrm{mL}$.

\section{DISCUSSION}

In our study, the initial IL-6 level was significantly associated with initial GCS at a prevalence rate of 11.4. In other words, patients with an initial IL-6 level of 100 $\mathrm{pg} / \mathrm{mL}$ or below had an 11.4-times higher chance of having an initial GCS over 8 . This is consistent with the study of Woicienchowxky et $\mathrm{al}^{4}$ stating that initial IL-6 plasma levels are associated with brain injury severity. The higher the initial IL-6 serum level, the higher the patient's risk of getting impaired consciousness (low GCS score). High IL-6 serum level of patients with pure brain injury showed neuroinflammation and damage of the blood brain barrier, which led to the release of IL-6 into systemic blood circulation., ${ }^{45}$

After surgery, IL-6 serum level had a downward trend. The post-operative IL-6 level was significantly associated with GCS 7 days post-surgery, meaning that surgery may reduce neuroinflammatory processes. Neurosurgical procedures aim to reduce intracranial pressure. In accordance with the study of Hergenroeder et al, ${ }^{16}$ high intracranial pressure is correlated with increased levels of IL-6. Intracranial pressure release after neurosurgical procedure can be ascribed to improvement of neuroinflammatory processes. ${ }^{16}$

After 3 months of follow up, lower post-operative IL-6 levels (under $100 \mathrm{pg} / \mathrm{mL}$ ) have 11.6-times higher chance of reaching the 3 months post-trauma GOS 'favorable'.

Although there was no association between the initial levels of uric acid and the initial GCS score, postoperative uric acid serum level decreased significantly on the seventh post-traumatic day. This finding is consistent with the results of Kinuta et $\mathrm{al}^{17}$ that xanthine oxidase is located mainly in endothelial cells (3.7-fold compared to the cerebral cortex). The capillary is probably the primary site of oxygen delivery and free radical reactions, which are induced by the xanthine-metabolizing system. ${ }^{17}$ Increased capillary permeability caused by endothelial injury leads to brain edema (secondary brain damage)..$^{2,3,17-19}$ Neurosurgery procedures - conducted to decrease the elevated intracranial pressure - may also reduce intracranial oxidative stress.
Even though there is no significant difference in the mean value of uric acid levels 3 months post-trauma between patient groups with 'unfavorable' and 'favorable' GOS, there is a difference of 0.6 in the standard deviation. According to Sloan et $\mathrm{al}^{20}$ in practical guidelines for assessing the statistical significance in changes of health-related quality of life in a clinical trials, it may be assumed that there is still the possibility of clinical significance with a larger number of samples. ${ }^{20}$

There is no significant association between MDA serum levels and both, GCS and GOS. The reason might be that our measurements were not carried out in serial order to find the highest MDA levels. In several studies, the measurement of MDA was performed in serial order in the first 48 hours revealed high MDA levels in conditions with increased intracranial pressure. ${ }^{9,21-23}$

Nevertheless, the significant decrease of post-surgical MDA levels in our study compared to initial MDA levels showed that neurosurgical procedures may also reduce the intracranial oxidative stress.

The autoantibody reaction to the NMDA receptor $(\mathrm{NR} 2 \mathrm{~A})^{24,25}$ is a humoral immune reaction. Dambinova et $\mathrm{al}^{26}$ measured NR2A antibody levels in serial order within the first 72 hours, found that the peak of increase was at the first 10 to 12 hours after ischemic cerebral vascular attack. ${ }^{26}$ Although the significant association between NR2A antibody serum levels and GCS, GOS and surgery were not found, there is still a possibility to obtain different results if NR2A antibody serum level is measured in serial order.

Highly reactive free radicals, such as hydroxyl or hydroperoxyl radicals, may be intercepted by the glutathione redox system including glutathione peroxidase, transferase and reductase. GSH transforms into oxidized glutathione (GSSG) during the glutathione peroxidase reaction and GSSG returns to GSH by glutathione reductase (redox cycle). GSH plays an important role in neutralizing free radicals and in maintaining protein thiols, in order to protect cells via the glutathione redox cycle against injury. ${ }^{27}$

We found no significant association between GSH serum levels with GCS, GOS and surgery. In traumatic brain injury, the leading mechanism is neuroinflammation, ${ }^{2,3}$ while glutathione and other antioxidants may play a major protective role in mutagenetic and apoptotic processes. On the other hand, it is difficult to separate mere anti-inflammatory from antioxidative protection because the one includes the other.

Among all variables compared in our multivariate analysis, neuroinflammation is the most important parameter, which 
has significant association with initial and post-operative GCS score and 3-months post-traumatic GOS.

In conclusion, neuroinflammation and oxidative stress may have prognostic values in brain-injured patients, in particular IL-6. Neurosurgical procedures may decrease the neuroinflammation process.

\section{Acknowledgment}

The authors would like to extend their gratitude to the Directorate of Research and Community Service, Universitas Indonesia, that have supported this study through The Competitive Research Grant Universitas Indonesia 2010 (Hibah Riset Unggulan Universitas Indonesia).

\section{REFERENCES}

1. Selladurai B, Reilly P, editors. Initial management of head injury: a comprehensive guide. Brisbane: McGraw-Hill Australia Pty Ltd; 2007. p. 1-28.

2. Longhi L, Saatman K. Cellular basic of injury and recovery from trauma. In: Winn HR, editor. Youmans neurological surgery. Philadelphia: Saunders; 1996. p. 5025-33.

3. Zwienenberf-Lee M, Muizelaar JP. Clinical pathophysiology of traumatic brain injury. In: Winn HR, editor. Youmans neurological surgery. Philadelphia: Saunders; 1996. p. 5039-58.

4. Woicienchowxky C, Schoning B, Cobanov J, Lanksch WR, Volk HD, Docke WD. Early IL-6 plasma concentrations correlate with severity of brain injury and pneumonia in brain-injured patients. J Trauma. 2002;52:339-45.

5. Swartz KR, Liu F, Sewell D, Schocet T, Campbell I, Sandor $\mathrm{M}$, et al. Interleukin-6 promotes post-traumatic healing in the central nervous system. Brain Res. 2001;896:86-95.

6. Schmidt OI, Infanger M, Heyde CE, Ertel W, Stahel F. The role of neuroinflammation in traumatic brain injury. Eur $\mathrm{J}$ Trauma. 2004;30:135-49.

7. BayirH,Kagan VE. Bench-to-bedside review: mitochondrial injury, oxidative stress and apoptosis - there is nothing more practical than a good theory. Crit Care. 2008;12:206.

8. Higgins P, Walters M, Dawson J. The potential for xanthine oxidase inhibition in the prevention and treatment of cardiovascular and cerebrovascular disease. Cardiovascular Psychiatry and Neurology. 2009, Article ID 282059.

9. Paolin A, Nardin L, Gaetani P, Rodriguez Y, Baena R, Pansarasa $\mathrm{O}$, et al. Oxidative damage after severe head injury and its relationship to neurological outcome. Neurosurgery. 2002;51:949-55.

10. Dringen R, Gutterer JM, Hirrlinger J. Glutathione metabolism in brain metabolic interaction between astrocytes and neurons in the defense against reactive oxygen species. Eur J Biochem. 2000;267:4912-6.

11. Townsend DT, Tew KD, Tapiero AH. The importance of glutathione in human disease. Biomed Pharmacother. 2003;57:145-55.
12. Bokesch PM, Izykenova GA, Justice JB, Easley KA, Dambinova SA. NMDA receptor antibodies predict adverse neurological outcome after cardiac surgery in high-risk patients. Stroke. 2006;37:1432-6.

13. Bullock MR, Chesnut R, Ghajar J, Gordon D, Servadei F, Hartl R, et al. Guidelines for the surgical management of traumatic brain injury. Neurosurgery. 2006;58(3):1-57.

14. Badiyono B, Moeslichan S, Sastroasmoro S, Budiman I, Purwanto H. Perkiraan besar sampel. Dasar-dasar metodologi penelitian klinis. Jakarta: Sagung Seto; 2002. p. 259-86. Indonesian.

15. Baldwin SA, Fugaccia I, Brown DR, Brown LV, Scheff SW. Blood-brain barrier breach following cortical contusion in the rat. J Neurosurg. 1996;85:476-81.

16. Hergenroeder GW, Moore AN, McCoy JP, Samsel W, Ward NH, Clifton GL, et al. Serum IL-6: a candidate biomarker for intracranial pressure elevation following isolated traumatic brain injury. J Neuroinflammation. 2010;7:19.

17. Kinuta Y, Kimura M, Itokawa Y, Ishikawa M, Kikuchi H. Changes in xanthine oxidase in ischemic rat brain. J Neurosurg. 1989;71:417-20.

18. Pacher P, Nivorozhkin A, Szabo C. Therapeutic effects of xanthine oxidase inhibitors: renaissance half a century after the discovery of allopurinol. Pharmacol Rev. 2006;58(1):87-114.

19. Ayer RE, Zhang JH. Oxidative stress in subarachnoid haemorrhage: significance in acute brain injury and vasospasm.Acta Neurochir Suppl. 2008;104:33-41.

20. Sloan J, Symonds T, Vargas-Chanes D, Fridley B. Practical guidelines for assessing the clinical significance of healthrelated quality of life changes within clinical trials. Drug Information Journal. 2003;37:23-31.

21. Shohami E, Gati I, Beit-Yannai E, Trembovler V, Kohen R. Closed head injury in the rat induces whole body oxidative stress: overall reducing antioxidant profile. J Neurotrauma. 1999;16:365-76.

22. Shohami E, Beit-Yannai E, Horowitz M, Kohen R. Oxidative stress in closed-head injury: brain antioxidant capacity as an indicator of functional outcome. J Cereb Blood Flow Metab. 1997;17:1007-19.

23. Bullock MR, Merchant RE, Choi SC, Gilman CB, Kreutzer JS, Marmarou A, et al. Outcome measures for clinical trials in neurotrauma. Neurosurg Focus. 2002;13:1-11.

24. Brennan AM, Suh SW, Won SJ, Narasimhan P, Kauppinen $\mathrm{TM}$, Lee $\mathrm{H}$, et al. NADPH oxidase is the primary source of superoxide induced by NMDA receptor activation. Nat Neurosci. 2009;12(7):857-63.

25. Papadia S, Hardingham GE. The dichotomy of NMDA receptor signaling. Neuroscientist. 2007;13(6):572-9.

26. Dambinova SA, Khounteev GA, Izykenova GA, Zavolokov IG, Ilyukhina AY, Skoromets AA. Blood test detecting autoantibodies to N-methyl-D-aspartate neuroreceptors for evaluation of patients with transient ischemic attack and stroke. Clin Chem. 2003;49(10):1752-62.

27. Kudo H, Mio T, Kokunai T, Tamaki N, Sumino K, Matsumoto S. Quantitative analysis of glutathione in human brain tumors. J Neurosurg. 1990;72:610-5. 